\title{
LIMBAH KERTAS DUPLEX UNTUK BAHAN CANTING CAP BATIK
}

\section{Duplex Paper Waste for Batik Stamp Materials}

\author{
Nurohmad Nurohmad ${ }^{1}$ dan Edi Eskak ${ }^{2}$ \\ ${ }^{1}$ Omah Kreatif Dongaji, Sawit, Panggungharjo, Sewon, Bantul, Yogyakarta, Indonesia \\ ${ }^{2}$ Balai Besar Kerajinan dan Batik, Jl. Kusumanegara No. 7 Yogyakarta, Indonesia
}

\begin{tabular}{lr}
\hline Korenspondesi Penulis & Naskah Masuk : 10 Maret 2019 \\
Email $\quad$ Rohmadnurohmad75@gmail.com dan eskakedi@gmail.com & Revisi 21 Maret 2019 \\
& Disetujui $: 26$ Juni 2019
\end{tabular}

Kata kunci: limbah kertas, duplex, batik cap, canting cap kertas

Keywords: paper waste, duplex, batik stamp, paper batik stamp

\section{ABSTRAK}

Limbah kertas kemasan yang paling banyak ditemui adalah jenis duplex. Bentuk lembaran dan ketebalan kertas duplex mempunyai kesamaan dengan plat tembaga sebagai bahan utama canting cap batik. Tujuan penelitian ini adalah memanfaatkan limbah kertas duplex untuk digunakan sebagai bahan pembuat canting cap batik. Metode yang digunakan adalah pengumpulan dan analisis data, perancangan motif canting cap batik, pembuatan canting cap, uji pengecapan, dan uji pewarnanaan batik. Fokus penelitian ini pada pemanfaatan limbah kertas duplex untuk pembuatan canting cap kertas. Hasilnya limbah kertas duplex dapat dimanfaatkan untuk membuat canting cap batik, dengan keunggulan yaitu: bahan mudah didapat, teknik pembuatan lebih mudah, harga lebih murah, dan sudah dapat digunakan untuk proses batik cap.

\begin{abstract}
The most commonly packaging paper waste found is duplex. Duplex paper have similar sheet shape and thickness with copper plate as the main material of batik stamp. The purpose of this research is to utilize duplex paper waste for the manufacture of batik stamp. The methods used are data collection, design batik stamp, batik stamp making, stamping, and batik coloring. This research focus on utilization of duplex waste for batik stamp making. The result is that duplex paper waste can be used to make batik stamp canting, with advantages namely: it was easy to obtain the materials, easier to manufactured the techniques, had cheaper prices, and it surely can be used for batik stamp process.
\end{abstract}




\section{PENDAHULUAN}

Pemanfaatan kertas untuk berbagai keperluan sehari-hari menyisakan limbah. Limbah kertas dapat dimanfaatkan kembali untuk berbagai keperluan sesuai jenis dan kondisi limbah. Pemanfaatan kembali limbah kertas merupakan aktualisasi cinta lingkungan hidup, karena turut menjaga kebersihan, sekaligus dapat mengerem laju penebangan pohon sebagai bahan utama industri kertas. Hal ini berarti dapat menghemat sumber daya alam dari eksploitasi yang berlebihan (Eskak, 2013a).

Limbah adalah bahan yang dibuang, atau hendak dibuang karena tidak lagi berguna sesuai peruntukannya. Limbah dikelompokkan sebagai limbah berbahaya atau tidak berbahaya (Moran \& Masciangioli, 2010). Limbah kertas termasuk jenis limbah yang tidak berbahaya. Kegiatan memanfaatkan limbah kertas merupakan partisipasi masyarakat dalam mengelola sampah. Masyarakat merupakan mahluk yang menghasilkan sampah, maka hendaknya juga bertanggung jawab serta berkewajiban mengelola sampah seperti yang diatur pemerintah Republik Indonesia dalam UU Nomor 18 Tahun 2008. Undangundang ini berisi tentang tanggung jawab terhadap pengelolaan sampah oleh negara dan masyarakat. Partisipasi masyarakat dapat dimulai dengan tidak membuang sampah sembarangan serta memisahkan sampah organik dan non organik, hingga menerapkan konsep 3R yaitu reduce, reuse, dan recycle. Recycle berarti daur ulang sampah menjadi produk baru yang bermanfaat serta memberikan nilai tambah. Beberapa komunitas kreatif pecinta lingkungan menyebutnya sebagai upcycle, yaitu cara baru untuk memanfaatkan barang-barang bekas menjadi suatu benda yang memiliki manfaat lain sehingga tidak perlu membuangnya (Eskak \& Salma, 2017). Recycle limbah kertas perlu dilakukan dengan memanfaatkan kreativitas, kebutuhan masyarakat, serta kearifan lokal. Kreativitas termasuk kepandaian seni yang dapat dimanfaatkan untuk berkarya yang berguna untuk meningkatkan kesejahteraan masyarakat (Eskak, 2014).

Limbah kertas yang akan digunakan adalah jenis karton bekas dos kemasan makanan jenis duplex (Gambar 1). Kotak karton atau sering disebut folding/individual carton amat populer dari semua packaging dan sering dipakai untuk kebutuhan yang paling sederhana sampai yang sulit (Julianti, 2018). Penggunaan yang paling sederhana antara lain untuk dos nasi dan dos snack. Kertas duplex dapat dikenali dari warnanya, satu sisi berwarna putih, sedangkan sisi lainnya berwarna abu-abu. Ketebalan kertas duplex dinyatakan dalam gram. Gramasi yang umum dipakai yakni 250, 310, 350, dan 400 gram. Gramasi dalam produk kertas menunjukkan tingkat ketebalan kertas, semakin besar gramasinya semakin tebal kertasnya (Lima Kegunaan Kertas Duplex untuk Kemasan Produk yang Menarik, 2018). Harga kertas duplex relatif murah dibandingkan harga jenis kertas karton lainnya.

Kertas duplex sebagai lembaran karton tebal mempunyai ukuran ketebalan yang sama dengan plat tembaga sehingga dapat digunting dan disusun menyerupai canting cap batik dari bahan tembaga. Menilik dari 
bentuk dan karakteristiknya yang tahan panas, maka kertas ini diharapkan dapat digunakan sebagai bahan baku dalam pembuatan canting cap. Canting cap umumnya terbuat dari jenis logam dan kayu (Hastuti \& Pristiwati, 2010). Bahan kayu sebagai selulosa alami yang masih solid dapat dimanfaatkan untuk pembuatan canting cap, maka kertas duplex yang asalmuasalnya terbuat dari pulp selulosa kayu, diduga dapat dimanfaatkan sebagai bahan pembuatan canting cap batik. Lembaran kertas duplex memiliki kemiripan rupa dengan plat tembaga, sehingga mudah dipotong dan dibentuk menjadi motif pada canting cap.

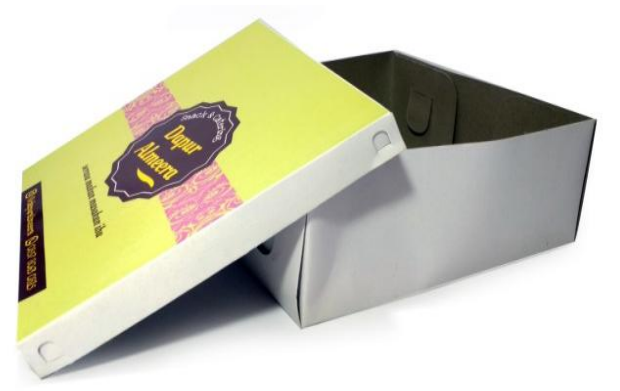

Gambar 1. Limbah kertas duplex

Canting cap merupakan alat untuk memproduksi batik (Sulistyono, Harnandito, \& Nasution, 2018), yang umumnya terbuat dari logam yang dipotong menjadi bentuk pita dan disusun menjadi semacam stempel motif batik yang digunakan untuk menempelkan lilin pada kain (Samsi, 2006). Canting cap batik yang terbaik terbuat dari tembaga (Soerjanto, 1975), namun harga tembaga relatif mahal dan pembuatannya memerlukan keahlian serta peralatan khusus sehingga harganya semakin mahal. Pemanfaatan kertas duplex dapat menjadi solusi karena teknik pembuatannya relatif mudah dengan harga bahan dan peralatan yang lebih murah. Tujuan penulisan ini adalah memanfaatkan limbah kertas karton duplex sebagai bahan pembuatan canting cap batik.

\section{METODOLOGI PENELITIAN}

\section{Bahan dan Alat}

Bahan dan alat yang digunakan dipilah menjadi 4 yaitu: untuk pengumpulan data, perancangan, pembuatan canting cap kertas, dan pembuatan batik. Adapun bahan dan alat yang digunakan yaitu: buku catatan, pulpen, kamera, komputer dengan program olah grafis dan olah data, printer, kertas gambar, pensil, karet penghapus, spidol hitam, penggaris, dan drawing pen 0.3 hitam, limbah kertas dos saji makan dan snack, gunting, lem blendok (perekat kuno/tradisional), lem kertas (glukol/g/ue stick), lem kayu (Polyvinyl Acetate/PVAc), lem kuning (Chloroprene Rubber), lem presto DN (resin alifatik), lem Korea G (Cyanocrylate Eti), penggaris stainless, gergaji, triplek/MDF, kayu, cutter, amplas halus, kain katun, malam batik cap, zat warna naphtol, kompor cap, loyang cap, meja cap, zat warna indigosol, neraca/timbangan warna, cawan peramu warna, sarung tangan karet, bejana, ember, alat pelorod, air tawar, setrika, dan penjemuran teduh.

\section{Prosedur Kerja}

Prosedur kerja dilakukan dengan tahap-tahap yang tergambarkan dalam bagan pada Gambar 2. Data yang diperlukan dalam penelitian ini diperoleh dari studi pustaka dan observasi. Studi pustaka dilakukan pada sumber yang 
berasal dari jurnal, buku, dan internet. Observasi dilakukan untuk mengamati jenisjenis limbah kertas, struktur canting cap, serta aspek-aspek lain yang mendukung penelitian ini. Pengamatan dilakukan secara mendalam terhadap suatu objek atau permasalahan (Eskak, 2013b), untuk mendapatkan insight yaitu sesuatu yang berharga yang akan diangkat sebagai subject matter (Marianto, 2011) dalam penelitian dan penciptaan ini

Insight yang didapatkan dapat berupa ide kreatif. Ide masih berupa imajinasi, maka perlu divisualkan dalam bentuk sketsa di kertas. Sketsa merupakan visualisasi awal dari suatu karya yang ingin diwujudkan (Eskak, 2013a). Dari sketsa-sketsa yang dihasilkan, kemudian dipilih yang terbaik untuk diproses menjadi desain. Desain kemudian dibuat gambar kerja skala 1:1 untuk diblat atau dipindahkan ke papan MDF atau triplek.

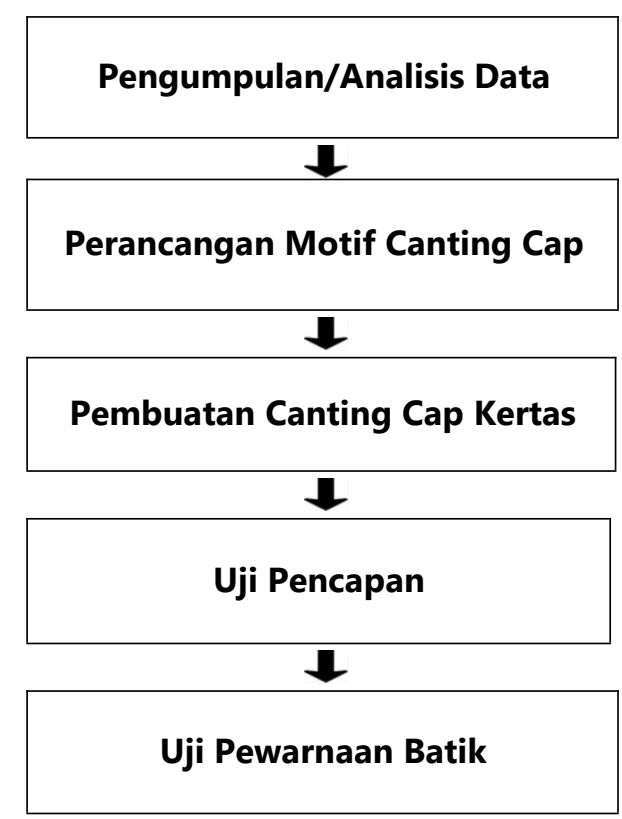

Gambar 2. Bagan penelitian pembuatan canting cap dari limbah kertas duplex
Kertas duplex dipotong-potong memanjang selebar $2 \mathrm{~cm}$, kemudian dengan perekat lem ditempelkan secara tegak lurus ke papan MDF atau triplek, dibentuk mengikuti motif cap yang akan dibuat (Gambar 3). Struktur bentuk canting cap kertas tidak berbeda dengan canting cap tembaga, namun karena jenis material yang sangat berbeda maka cara perakitan dan perekatannya memerlukan teknik dan bahan perekat yang berbeda pula. Setelah canting cap kertas selesai diwujudkan maka dilakukan uji pemakaian dalam proses pengecapan malam batik ke media kain.

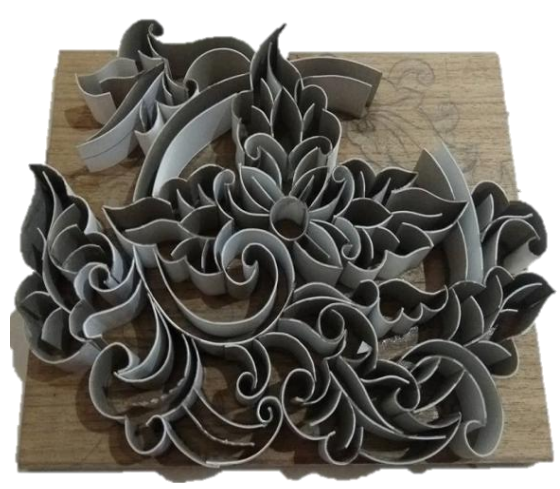

Gambar 3. Penyusunan potongan kertas menjadi motif canting cap

\section{HASIL DAN PEMBAHASAN}

Hasil

Hasil kegiatan ini dapat diketahui bahwa limbah kertas duplex dapat dimanfaatkan untuk membuat canting cap, yang kemudian disebut sebagai "canting cap kertas". Canting ini dapat berfungsi untuk mengecapkan atau melekatkan lilin batik panas pada kain dengan baik. Hasil pelekatan malam/lilin dapat diproses sebagaimana proses batik umumnya, khususnya dalam pewarnaan dengan hasil baik. Berdasarkan hasil yang diperoleh maka 
alat canting cap kertas layak digunakan sebagai canting cap batik.

\section{Pembahasan}

Berdasarkan survei lapangan di Bantul, limbah kertas kemasan yang paling banyak ditemukan adalah jenis duplex. Jenis kertas ini memiliki ketebalan yang memadai sehingga banyak digunakan untuk kemasan dos nasi, dos snack, dos bakpia, dos martabak, dan sebagainya. Selain kertas duplex sebenarnya terdapat beberapa jenis karton kemasan lainnya, namun limbah yang terbanyak ditemukan adalah jenis kertas duplex. Kertas duplex masuk dalam grade 3 yaitu material kemasan dengan kualitas cukup. Adapun jenis-jenis karton atau kertas tebal yang umumnya digunakan untuk bahan kemasan dapat dilihat dalam Tabel 1.

Tabel 1. Survei limbah karton kemasan

\section{No Jenis Karton Grade Keterangan}

\begin{tabular}{clcc}
\hline 1 & Art carton & $1-2$ & $\begin{array}{c}\text { Sedikit } \\
\text { ditemukan }\end{array}$ \\
$\mathbf{3}$ & Cast coated & $1-3$ & $\begin{array}{c}\text { Cukup } \\
\text { ditemukan }\end{array}$ \\
$\mathbf{4}$ Ivory & 3 & $\begin{array}{c}\text { Banyak } \\
\text { ditemukan }\end{array}$ \\
& 2 & $\begin{array}{c}\text { Sedikit } \\
\text { ditemukan }\end{array}$
\end{tabular}

Keterangan grade:

1 = Sangat Bagus

2 = Bagus

3 = Cukup

4 = Kurang

5 = Jelek
Kertas kemasan memiliki sifat-sifat antara lain: stiffness, substance, thickness, grain direction, moisture content, brightness, dan smoothness (Calver, 2007). Stiffness yaitu derajat kekakuan. Substance yaitu kepadatan karton, berpengaruh pada berat karton per meter persegi. Thickness yaitu ketebalan karton. Grain direction yaitu arah serat karton. Moisture content yaitu kelembaban karton. Brightness yaitu jumlah sinar biru yang dipantulkan oleh karton, hal ini berkaitan dengan eksplorasi grafis cover kemasan. Smoothness yaitu kehalusan karton (Julianti, 2018). Adapun yang berpengaruh langsung pada pembuatan canting cap adalah: stiffness (derajat kekakuan), substance (kepadatan), dan thickness (ketebalan).

Tabel 2. Gramasi/ketebalan kertas duplex

\begin{tabular}{cccc} 
No & $\begin{array}{c}\text { Gramasi } \\
\text { (gram) }\end{array}$ & $\begin{array}{c}\text { Mayoritas } \\
\text { Limbah }\end{array}$ & $\begin{array}{c}\text { Penggunaan } \\
\text { Motif }\end{array}$ \\
\hline $\mathbf{1}$ & 250 & Dos snack & Garis isian \\
$\mathbf{2}$ & 300 & Dos snack & Garis isian \\
$\mathbf{3}$ & 350 & Dos nasi & Garis utama \\
$\mathbf{4}$ & 400 & Dos nasi & Garis utama
\end{tabular}

Sifat-sifat kertas duplex secara umum mendukung karakteristik material yang sesuai untuk pembuatan motif canting cap dengan teknik potong-rangkai-rekat. Tingkat ketebalan produk kertas industri ditunjukkan dengan standar gramasi (Lima Kegunaan Kertas Duplex untuk Kemasan Produk yang Menarik, 2018). Tingkat ketebalan kertas duplex dimanfaatkan untuk membentuk motif, untuk membuat garis 
motif utama/klowong digunakan duplex 350-400 gram. Untuk membuat garis isian digunakan duplex 250-300 gram (Tabel 2).

Lem atau perekat dalam membentuk motif menggunakan 6 jenis lem sebagai perbandingan, yaitu lem blendok (perekat kuno/tradisional), lem kertas (glukol/glue stick), lem kayu (Polyvinyl Acetate/PVAc), lem kuning (Chloroprene rubber), lem presto DN (resin alifatik), lem Korea G (Cyanocrylate Eti). Lem blendok mempunyai kekuatan yang baik (Eskani, Perdana, Eskak, \& Sumarto, 2017), namun waktu keringnya lama dan hasilnya kurang rapi. Penggunaan lem kertas cukup cepat kering dan cukup rapi, namun kurang kuat. Lem kayu hasilnya kuat, namun lama kering dan kurang rapi. Lem kuning hasilnya cepat kering, cukup kuat, dan cukup rapi, namun jenis lem ini kurang tahan terhadap panas. Lem presto hasilnya sangat kuat, namun keringnya lama dan hasilnya kurang rapi. Lem Korea $G$ hasilnya cukup kuat dan rapi serta proses pengeringannya sangat cepat.

Hasil yang lebih disukai adalah perekatan dengan menggunakan lem Korea atau Cyanoaacrylate adhesive. Lem ini penggunaannya praktis, dapat menjangkau potongan yang tipis maupun yang kecil, serta cepat kering. Dengan menggunakan lem ini proses membuat canting cap kertas lebih cepat selesai. Hasil secara rinci dapat dilihat dalam Tabel 3.

Setelah terbentuk menjadi motif cap, permukaannya diratakan dengan pengamplasan. Pengamplasan dilakukan dengan hati-hati agar tidak merusak motif yang sudah jadi. Motif yang sudah jadi dalam MDF/triplek kemudian diberi kayu sebagai penguat serta dipasang tangkai pegangan. Pembuatan canting cap batik dari bahan limbah kertas duplex telah selesai, dan siap digunakan untuk proses pengecapan lilin batik panas ke permukaan kain

Tabel 3. Bahan perekat/lem

No Perekat $\begin{gathered}\text { Cepat Kuat Rapi } \\ \text { Kering }\end{gathered}$

\begin{tabular}{lllll}
\hline $\mathbf{1}$ & Lem blendok & 4 & 2 & 4 \\
$\mathbf{2}$ & Lem kertas & 3 & 4 & 3 \\
$\mathbf{3}$ & Lem kayu & 4 & 2 & 4 \\
$\mathbf{4}$ & Lem kuning & 2 & 3 & 3 \\
$\mathbf{5}$ & Lem presto & 4 & 1 & 4 \\
$\mathbf{6}$ & Lem Korea & 1 & 3 & 2 \\
\hline
\end{tabular}

$$
\begin{aligned}
& \text { Keterangan: } \\
& 1=\text { Sangat } \\
& 2=\text { Baik } \\
& 3=\text { Cukup } \\
& 4=\text { Kurang }
\end{aligned}
$$

\section{Uji Pengecapan}

Alat produksi harus dapat digunakan untuk bekerja sebagaimana tujuan alat tersebut dibuat. Canting cap kertas kegunaannya adalah untuk mencapkan atau melekatkan malam batik panas ke kain. Bahan kertas sebagaimana bahan kayu bukanlah penghantar panas yang baik, oleh karena itu perlu dilakukan uji pelekatan lilin batik. Hasil uji pencapan dapat dilihat pada Gambar 4, hasilnya sesuai dengan kriteriakriteria lekatan malam batik yang akan menghasilkan batikan yang baik. Kriteria- 
kriteria tersebut antara lain: tapak malam yang ngawat dan kuat, rapi membentuk pola motif, dan malam mampu menembus kain, sehingga menghasilkan batik cap yang berkualitas sesuai standard SNI 08-35311989: Ciri Batik Cap.

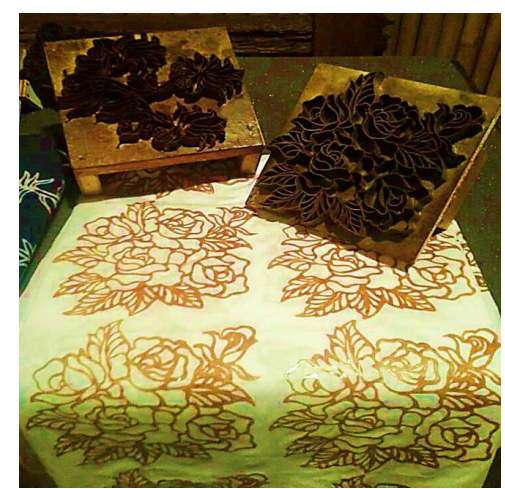

Gambar 4. Uji pengecapan canting cap kertas

\section{Uji Pewarnaan Batik}

Kualitas pelekatan lilin yang baik perlu diuji lebih lanjut pada kualitas pencelupan warna. Hal ini dilakukan untuk menguji kekuatan lekatan malam batik dalam merintangi resapan warna, hasilnya lilin mampu merekat kuat merintangi resapan zat warna, menghasilkan motif yang tampak jelas dan bersih. Gambar 5 menunjukkan tapak motif garis klowongan yang jelas dan rapi. Gambar 6 menunjukkan tapak motif tembokan/block yang bersih dan rapi.

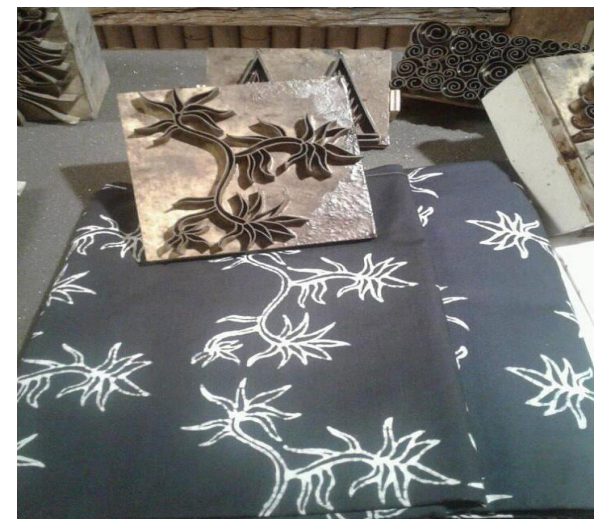

Gambar 5. Hasil cap klowong

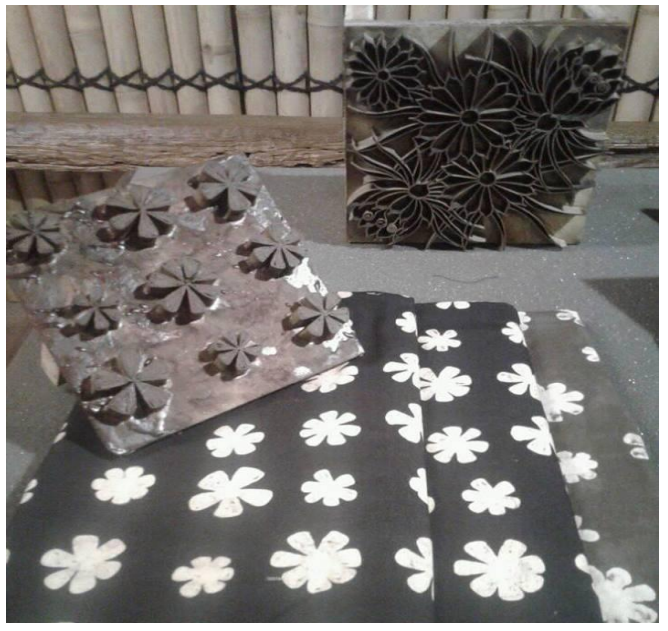

Gambar 6. Hasil cap tembokan

Dengan demikian dapat disimpulkan bahwa pelekatan lilin berkualitas bagus/baik, sehingga motif yang terbentuk dari repetisi pencapan terlihat rapi dan bersih. Berdasarkan pencermatan uraian di atas, kain batik yang dihasilkan diorientasikan untuk memenuhi standard SNI 08-35311989: Ciri Batik Cap.

\section{Tinjauan Nilai Kreatif Canting Cap Kertas}

Seni dan kreativitas senantiasa seiring sejalan. Dengan mendayakan kreativitas manusia akan mampu mencari solusi dari berbagai permasalahan hidup. Seni menjadi daya hidup (Marianto, 2017) adalah suatu keniscayaan karenanya perlu dimanfaatkan kegunaannya baik secara personal maupun sosial (Feldman, 1967) menuju kesejahteraan hidup manusia. Orang yang penuh daya kreatif dan mampu memanajemen diri dengan baik, atau dimanajeri dengan baik oleh manajer profesional maka secara ekonomi, hidupnya akan lebih sejahtera.

Kreasi canting cap batik dari limbah kertas duplex dihasilkan dari pengamatan terhadap hal yang sederhana, bahkan biasanya luput dari perhatian orang pada 
umumnya. Dengan melihat limbah kertas secara berbeda mampu mencetuskan ide, menghadirkan realitas baru dalam memaknai limbah kertas, yang mampu terkoneksi dengan ide tentang canting cap batik. Ada relasi-relasi imajiner yang mampu menghadirkan suatu kebaruan ataupun suatu solusi. Marianto (2004) dalam hal ini menyatakan bahwa realitas baru terjadi ketika kita memandangnya, bagaimana kita memandangnya, dan bagi orang kreatif ia mampu untuk melihat ruang-ruang imajiner dan dalam ruang tersebut ia mampu mengeluarkan potensipotensi yang ia miliki.

Potensi-potensi bahan limbah kertas duplex terkoneksi dengan potensi bentuk dan kegunaan canting cap batik, maka tercetuslah ide memanfaatkan bahan kertas tersebut sebagai imitasi plat tembaga dalam pembuatan canting cap. Ada manfaat besar yang didapatkan dari kreativitas ini, suatu hal besar yang didapatkan dari pengamatan terhadap hal yang danggap kecil atau tak berharga. Harga canting cap tembaga ukuran $20 \times 20 \mathrm{~cm}$, saat ini antara Rp 750.000,- hingga Rp 1.000.000,-, dengan lama pengerjaan antara 3-6 hari, sedangkan dengan kertas duplex maka didapatkan harga antara Rp 100.000,- hingga Rp 250.000,- dengan lama pengerjaan 1 hari.

Canting cap merupakan alat penting dalam usaha batik cap, namun banyak dikeluhkan oleh IKM batik pemula karena harganya yang mahal. Canting cap tembaga, memiliki harga yang mahal karena dibuat dari bahan baku yang relatif mahal dan sulit dalam proses pembuatannya karena menggunakan alat dan bahan khusus, serta dikerjakan oleh tenaga profesional. Pemanfaatan limbah kertas duplex dapat menjadi solusi terhadap permasalahan tersebut. Bahan dan alat yang diperlukan dalam pembuatan canting cap kertas murah dan mudah didapatkan. Teknik pembuatannya relatif mudah dan tidak melalui tahapan-tahapan yang rumit, sehingga para IKM batik pemula dapat membuatnya sendiri.

Seni adalah kemampuan istimewa dalam mengubah suatu ide menjadi konsep kreatif yang dinyatakan menjadi suatu yang menarik, fungsional, atau inspiratif (Marianto, 2017). Kreativitas membuat canting cap kertas adalah upaya untuk mewujudkan teori seni tersebut di atas. Kreativitas ini diharapkan dapat mendukung pelestarian batik yang secara teknik dijauhi generasi muda karena dianggap kuno dan tidak kreatif (Eskak, 2013c) serta mahal. Dengan lestarinya batik asli yang sesuai dengan SNI 0239 (Batik- Pengertian dan Istilah) 2014, selaras dengan SNI 08-35311989 (Ciri Batik Cap), maka kekayaan tradisi batik dapat dimanfaatkan untuk mendukung peningkatan kesejahteraan masyarakat. Kekayaaan budaya tradisional dalam era industri kreatif dewasa ini dapat dijadikan sumber inspirasi penciptaan seni kreatif dan inovatif sesuai dinamika zaman (Yoga \& Eskak, 2015). Solusi kreatif tidak harus sesuatu hal yang canggih, tetapi dapat sesuatu hal yang sederhana namun tepat guna, seperti kreativitas canting cap kertas ini. 


\section{KESIMPULAN DAN SARAN}

\section{Kesimpulan}

Daya kreatif dapat dimanfaatkan untuk menyelesaikan berbagai permasalahan hidup. Limbah kertas kemasan yaitu jenis karton duplex dapat dimanfaatkan untuk pembuatan canting cap batik. Uji pelekatan lilin panas dapat menghasilkan tapak lilin yang rapi dan kuat. Uji pewarnaan batik menunjukkan bahwa malam yang dicapkan mampu menahan resapan zat warna, sehingga menghasilkan motif yang rapi dan bersih, baik motif klowongan maupun motif tembokan.

\section{Saran}

Perlu dikembangkan pemanfaatan jenis-jenis kertas karton yang lainnya untuk pembuatan canting cap batik. Perlu dilakukan penelitian lebih lanjut terkait kualitas cap yang dihasilkan dan ketahanan (live time) serta kehandalan canting cap yang dihasilkan. Diseminasi juga perlu dilakukan agar teknologi sederhana namun tepat guna ini, secara cepat dapat dinikmati manfaatnya oleh masyarakat yang memerlukannya. Tulisan ini juga diharapkan dapat menginspirasi kerja-kerja kreatif yang lainnya.

\section{KONTRIBUSI PENULIS}

Penulis pertama maupun penulis kedua merupakan kontributor utama dalam penulisan Limbah Kertas Duplex Untuk Bahan Canting Cap Batik ini.

\section{UCAPAN TERIMA KASIH}

Terimakasih disampaikan kepada Omah Kreatif Dongaji Bantul dan Balai Besar
Kerajinan dan Batik, serta pihak-pihak yang turut membantu terlaksananya penelitian ini.

\section{DAFTAR PUSTAKA}

Calver, G. (2007). What is Packaging Design. Singapore: Page One Publishing Private Limited.

Eskak, E., dan Salma, I. R. (2017). Minat Konsumen Terhadap Desain Produk Tas dari Limbah Ban Dalam di Yogyakarta. In Prosiding Seminar Nasional Kulit, Karet dan Plastik ke-6 (pp. 75-85). Yogyakarta: Balai Besar Kulit Karet dan Plastik. Retrieved from http://prosiding.bbkkp.go.id/index.php/SK KP/article/view/311/93

Eskak, E. (2013). Mendorong Kreativitas Dan Cinta Batik Pada Generasi Muda Kritik Seni Karya Pemenang Lomba Desain Batik Bbkb 2012. Dinamika Kerajinan Dan Batik, 30(1), 1-10.

https://doi.org/http://dx.doi.org/10.22322/ dkb.v30i1

Eskak, E. (2013a). Metode Pembangkitan Ide Kreatif Dalam Penciptaan Seni. Corak, 2(2), 167-174. https://doi.org/DOI: 10.24821/corak.v2i2.2338

Eskak, E. (2013b). Rupa Karsa: Eksp/rorasi Limbah Dalam Seni. Institut Seni Indonesia Yogyakarta.

Eskak, E. (2014). Pemanfaatan Limbah Ranting Kayu Manis (Cinnamomun Burmanii) untuk Penciptaan Seni Kerajinan dengan Teknik Laminasi. Dinamika Kerajinan Dan Batik, 31(2), https://doi.org/http://dx.doi.org/10.22322/ dkb.v31i2.1068.g924

Eskani, I.N., Perdana, A., Eskak, E. \& Sumarto, H. (2017). Getah Pohon Kudo (Lannea Coromandelica) Sebagai Alternatif Perekat Untuk Produk Kerajinan. Dinamika Kerajinan Dan Batik, 34(1), 19-24. https://doi.org/http://dx.doi.org/10.22322/ dkb.v34i1.2265.g2302

Feldman, E. B. (1967). Art as image and idea. New Jersey: The University of Georgia Prentice Ihwall, Englewood Cliff.

Hastuti, L.S.H. \& Pristiwati, E. (2010). Tinjauan Tekno Ekonomi Cap Batik dari Bahan Kayu. Dinamika Kerajinan Dan Batik, 27(1), 9-20. 
https://doi.org/http://dx.doi.org/10.22322/

dkb.v27i1.1127.g950

Julianti, S. (2018). The Art of Packaging. Jakarta: Gramedia Pustaka Utama.

Lima Kegunaan Kertas Duplex untuk Kemasan Produk yang Menarik. (2018). Retrieved September 26, 2018, from https://importer.co.id/kertas-duplex

Marianto, M. D. (2004). Teori Quantum, Untuk Mengkaji Fenomena Seni. Yogyakarta: Lembaga Penelitian ISI Yogyakarta.

Marianto, M. D. (2011). Menempa Quanta Mengurai Seni. Yogyakarta: BP ISI Yogyakarta.

Marianto, M. D. (2017). Art and Life Force in a Quantum Perspektive. Yogyakarta: Scritto Book Publisher.

Moran, L. \& Masciangioli, T. (2010). Chemical Laboratory Safety and Security a Guide to Prudent Chemical Management. Washington DC: The National Academies Press.

RI (Republik Indonesia). Undang-Undang No. 18 Tahun 2008 tentang Pengelolaan Sampah (2008). Republik Indonesia.

Samsi, S. S. (2006). Canting Tulis dan Canting Cap. Yogyakarta: Yayasan Batik Indonesia.

SNI 0239. Batik - Pengertian dan Istilah (2014). Republik Indonesia: Badan Standardisasi Nasional.

SNI 08-3531-1989. Ciri Batik Cap. (1989). Republik Indonesia: Badan Standardisasi Nasional.

Soerjanto, T. T. (1975). Penelitian Tembaga Untuk Canting Cap. Balai Penelitian Batik dan Kerajinan, Yogyakarta.

Sulistyono, S., Harnandito , P., \& Nasution, A. T. (2018). Canting Cap Model Pin Art. In Prosiding Hasil Litbang Unggulan Kementerian Perindustrian. Jakarta: Badan Penelitian dan Pengembangan Industri.

Yoga, W. B. S., \& Eskak, E. (2015). Ukiran Bali Dalam Kreasi Gitar Elektrik. Dinamika Kerajinan Dan Batik, 32(2), 117-126. https://doi.org/http://dx.doi.org/10.22322/ dkb.v32i2.1367.g1156 